\title{
Adsorption of Naproxen Sodium from Aqueous Solutions on Commercial Activated Carbons
}

\author{
Joanna Lach ${ }^{1 *}$, Anna Szymonik ${ }^{1}$ \\ 1 Czestochowa University of Technology, Faculty of Infrastructure and Environment, Brzeźnicka Str. 60a, \\ 42-200 Częstochowa, Poland \\ * Corresponding author's e-mail: jlach@is.pcz.czest.pl
}

\begin{abstract}
The pollution of surface and drinking water with pharmaceuticals is one of the growing problems. One of the groups used in large quantities involves nonsteroidal anti-inflammatory drugs which can be bought without a prescription. This group includes naproxen, which was identified in wastewater, surface water and even drinking water all over the world. The aim of the study was to assess the opportunities for the removal of naproxen sodium from water using carbon sorbents. The measurements were carried out for three commercial microporous (WG-12 and F-300) and micro-mesoporous (ROW 08 Supra) activated carbons. The kinetics and statics of adsorption were studied. The adsorption from solutions with $\mathrm{pH}$ from 6 to 10 and temperature from $20^{\circ} \mathrm{C}$ to $40^{\circ} \mathrm{C}$ was analysed. It was found that the higher the $\mathrm{pH}$, the lower the adsorption and the higher the temperature, the greater the adsorption of naproxen sodium. The highest adsorption of naproxen sodium was obtained for the F-300 activated carbon, whereas the lowest - for the ROW 08 Supra activated carbon. It was found that the adsorption results depend on many factors, the most important of which include hydrogen bonds between carboxyl groups of naproxen sodium and phenolic groups on the surface of activated carbons and electrostatic repulsion between the anions of naproxen sodium and negatively charged the surface of the activated carbon. The results of adsorption kinetics were described with the following models: pseudo-first order and pseudo-second order, intraparticle diffusion, and Elovich. The highest values of correlation coefficient $\mathrm{R}^{2}$ were obtained for the pseudo-second order and Elovich model. The results of adsorption statics were described using the Freundlich, Langmuir, and Temkin models. A good match between isotherms and the obtained results was obtained for the Freundlich and Temkin equations. It was found based on the adsorption intensity $1 / n$ and distribution coefficient $R_{L}$ that this process was beneficial for all the considered activated carbons and the investigated adsorption conditions.
\end{abstract}

Keywords: naproxen sodium; activated carbon, adsorption

\section{INTRODUCTION}

The pollution of the environment by pharmaceuticals and protection against their effects is an increasingly common topic of research. The high consumption of drugs results in their presence in raw and treated wastewater, surface water, groundwater and even drinking water all over the world (Lach et al. 2018; Szymonik et al., 2017). Although this problem has been addressed for many years, no standard has been established to date and there are no legal documents specifying the permissible contents of pharmaceuticals in the raw sewage discharged from wastewater treatment plants, and thus released to ecosystems. The most common pharmaceuticals identified in the aquatic environment are beta-blockers, nonsteroidal anti-inflammatory drugs, antibiotics, female sex hormones, lipid metabolism regulators and antiepileptic drugs (Nikolaou et al., 2007). As early as 2009, de Voogt et al. found that the substances that deserve special attention include atenolol, bezafibrate, ciprofloxacin, diclofenac, erythromycin, gemfibrozil, ibuprofen, carbamazepine, naproxen and sulfamethoxazole, since they are highly toxic to the living organisms, have a high persistence in the environment and are consumed in large quantities. These researchers 
postulated that these substances should be monitored first (Voogt et al., 2009). However, in 2012, the European Commission added only diclofenac, ethinylestradiol and estradiol (Annex of Directive 2000/60/EC of European Parliament and the Council on priority substances in the field of water policy, Brussels $31.01 .2012 ; 2011$ ) to the list of compounds the concentrations of which in the EU waters should be monitored. The studies devoted to the problem of environmental pollution with pharmaceuticals are constantly being conducted, which is evidenced by the fact that on 11 March 2019, the European Commission issued a communication entitled „European Union Strategic Approach to Pharmaceuticals in the Environment".

Due to their anti-inflammatory, analgesic and antipyretic effects, the nonsteroidal anti-inflammatory drugs (ibuprofen, naproxen, diclofenac, ketoprofen) are often used and commonly detected in the aquatic environment (Bui and Choi, 2010; Onal et al., 2007). These pharmaceuticals are considered to be of high environmental risk, even if they occur in water in trace (ng/L) or low amounts $(\mu \mathrm{g} / \mathrm{L})($ Hernando et al., 2006; Manzo et al., 2014) . These compounds are often removed in conventional wastewater treatment plants with low efficiency (Feng et al., 2013).

Naproxen is widely used in medicine and veterinary medicine as an analgesic, anti-inflammatory and antipyretic agent. Despite the lack of monitoring of this compound, its presence was found in the surface waters of many countries, e.g. Poland $(300 \mathrm{ng} / \mathrm{L})$ (Baranowska and Kowalski, 2012), Czech Republic (180 ng/L) (Baranowska and Kowalski, 2012), Sweden (130 ng/L) (Daneshvar et al., 2010), Hungary (62 ng/L) (Helenkar et al., 2010), China (40 ng/L) (Wang et al., 2010), Italy (10 ng/L) (Patrolecco et al., 2015), France (9 ng/L) (Togola and Budzinski, 2008), Finland (3.3 ng/L) (Lindholm-Lehto et al., 2016), France (1 ng/L) (Minguez et al., 2016). The presence of naproxen in the surface water is a consequence of incomplete removal of this drug in conventional wastewater treatment plants. The presence of naproxen was found in the treated wastewater in e.g. France $(3210 \mathrm{ng} / \mathrm{L}$ (Santos et al., 2005) and $289 \mathrm{ng} / \mathrm{L}$ (Togola and Budzinski, 2008)), Germany (300 ng/L) (Kasprzyk-Hordern et al., 2007), Spain (91 ng/L) (Boleda et al., 2011), and Poland (82 ng/L) (Czerwiński et al., 2015). This medicine was also present in drinking water in Poland (13 ng/L) (Zgoła-Grześkowiak, 2010),
Spain (0.5 ng/L) (Carmona et al., 2014), and France $(0.2 \mathrm{ng} / \mathrm{L})$ (Togola and Budzinski, 2008).

The analysis on the usefulness of various methods of removing naproxen revealed that high efficiency was obtained in the cases of using oxidation, membrane and adsorption methodologies (Klavarioti et al., 2009; Monteiro and Boxall, 2010; Tambosi et al., 2010). However, it should be stressed that in many cases, the naproxen oxidation products are more toxic than the parent compound (Stancova et al., 2015). Taking into account the high efficiency of adsorption, the lack of by-products and the ease of the process, this methodology should be considered for the removal of naproxen. To date, the topic of naproxen adsorption has been discussed by few researchers and requires more extensive analysis.

The aim of this paper was to investigate the potential of using commercial carbon sorbents to remove naproxen sodium from water, analyse the kinetics and statics of adsorption and to evaluate the effect of process conditions on the process efficiency.

\section{METHODOLOGY}

\section{Naproxen sodium adsorption}

The naproxen sodium used in the experiment was produced by Sigma Aldrich. The characteristics of naproxen sodium are shown in Table 1. The concentrations were determined with the spectrophotometric method (UV-vis) at $\lambda=230 \mathrm{~nm}$ (Attia et al., 2013; Onal et al., 2007). The properties of sodium diclofenac are presented in Table 1.

\section{The kinetics and statics of adsorption}

The conditions of conducting the process of adsorption kinetics and statics are presented in Table 2. The experiments were carried out for a $0.25 \mathrm{~L}$ solution. The solution with activated carbon was mixed with the rotational speed of $160 \mathrm{rpm}$. The adsorption kinetics examinations were conducted for $10 \mathrm{~h}$ taking samples every 1 $\mathrm{h}$, whereas adsorption statics - for $24 \mathrm{~h}$ (10 h of mixing and $14 \mathrm{~h}$ of contact without mixing).

The following models were used to describe the kinetics of adsorption: pseudo-first-order, pseudo-second order, Elovich, intraparticle diffusion model (Weber-Morris). The adsorption statics were described using the models developed by 
Table 1. Physical and chemical properties of chloramphenicol (Farmakopea Polska, 2008; Naproxen sodium)

\begin{tabular}{|c|c|c|c|c|c|c|}
\hline Molecular structure & $\begin{array}{c}\text { Molecular } \\
\text { formule }\end{array}$ & $\begin{array}{c}\text { Molecular } \\
\text { weight, g/mol }\end{array}$ & Solubility, g/L & pKa & $\begin{array}{c}\text { The degree of } \\
\text { ionization, \%** }\end{array}$ & $\begin{array}{c}\text { pH of the } \\
\text { solution }\end{array}$ \\
\hline
\end{tabular}

* This concerns $1 \mathrm{mmol} / \mathrm{L}$ solution.

** Calculated using the Henderson and Hasselbach equations.

Table 2. Conditions of the naproxen sodium adsorption

\begin{tabular}{|l|c|c|c|c|}
\hline \multicolumn{1}{|c|}{ Process } & Concentration, $\mathrm{mg} / \mathrm{L}$ & $\mathrm{pH}$ of the solution & $\begin{array}{c}\text { Process } \\
\text { temperature, } \mathrm{K}\end{array}$ & Dose AC, g/L \\
\hline Adsorption kinetics & 252 & 7 & 293 & 4 \\
\hline Adsorption statics & $\begin{array}{c}252 ; 378 ; 504 ; 630 ; 756 ; \\
1008 ; 1261\end{array}$ & $6,8,10$ & $292,303,313$ & 4 \\
\hline Effect of dose AC & 252 & 7 & 293 & $1 ; 2 ; 3 ; 4 ; 5 ; 6 ; 7 ; 8 ; 9 ; 10$ \\
\hline
\end{tabular}

Langmuir, Freundlich, and Temkin (Dada et al., 2012; Tran et al., 2017; Tran et al., 2017). Furthermore, the $\mathrm{R}_{\mathrm{L}}$ separator was calculated based on the Langmuir isothermal constants. The constants of these equations were calculated from non-linear forms using Microsoft Excel Solver.

\section{Activated carbons}

Commercial activated coals used in water treatment plants: ROW 08 Supra (Norit, Poland), F-300 (Chemviron Carbon) and WG-12 (Gryfskand), were used in the examinations. These are microporous sorbents, with large specific surfaces and high sorption properties compared to the test substances (Table 3).

An FTIR Spectrum 2000 spectrometer (Perkin-Elmer) was used to determine the FTIR transmission spectra (Lach, 2019).

\section{RESULTS}

\section{Naproxen sodium adsorption kinetics}

The naproxen sodium adsorption kinetics with the $252 \mathrm{mg} / \mathrm{L}$ solution (Fig. 1) was analysed for all activated carbons used in the study. The research was conducted for $10 \mathrm{~h}$, with the samples taken every $1 \mathrm{~h}$. The adsorption equilibrium was established for all activated carbons at that time. The shortest time to determine the adsorption equilibrium was obtained for the F-300 activated carbon $(5 \mathrm{~h})$. For other carbon sorbents (ROW 08 Supra and WG-12), this time was $9 \mathrm{~h}$. In this study, it was assumed that the adsorption equilibrium occurs when the change of concentration in the solution within $1 \mathrm{~h}$ is less than $1 \%$ of the initial concentration.

Table 3. Properties of activated carbons used in tests (Lach, 2019)

\begin{tabular}{|l|c|c|c|c|}
\hline \multirow{2}{*}{ Parameter } & \multirow{2}{*}{ Unit } & \multicolumn{3}{c|}{ Activated carbons } \\
\cline { 3 - 5 } & & ROW 08 & F-300 & WG-12 \\
\hline Surface area, & $\mathrm{m}^{2} / \mathrm{g}$ & $897 \pm 30$ & $847 \pm 29$ & $1034 \pm 37$ \\
\hline $\mathrm{V}_{\text {micr. }}$ & & 0.436 & 0.476 & 0.524 \\
$\mathrm{~V}_{\text {meso. }}$ & $\mathrm{cm}^{3} / \mathrm{g}$ & 0.453 & 0.294 & 0.066 \\
$\mathrm{~V}_{\text {total. }}$ & & 1.135 & 0.987 & 0.995 \\
\hline $\mathrm{pH}$ of water extract & & 6.67 & 7.15 & 28.62 \\
\hline Methylene blue number & $\mathrm{LM}$ & 34 & 31 & 1117 \\
lodine adsorption & $\mathrm{LI}, \mathrm{mg} / \mathrm{g}$ & 1091 & 1055 & 0.675 \\
\hline Total acidic group, $\mathrm{A}$ & $\mathrm{mmol} / \mathrm{g}$ & 0.672 & 0.350 & 0.288 \\
\hline Total basic group, $\mathrm{B}$ & $\mathrm{mmol} / \mathrm{g}$ & 0.580 & 0.660 & 79.00 \\
\hline Elementary composition & & & 85.25 & 1.252 \\
$\mathrm{C}$ &,$\%$ & 80.05 & 0.771 & 0.813 \\
$\mathrm{H}$ & & 1.419 & 0.725 & \\
$\mathrm{~N}$ & & 0.932 & & \\
\hline
\end{tabular}




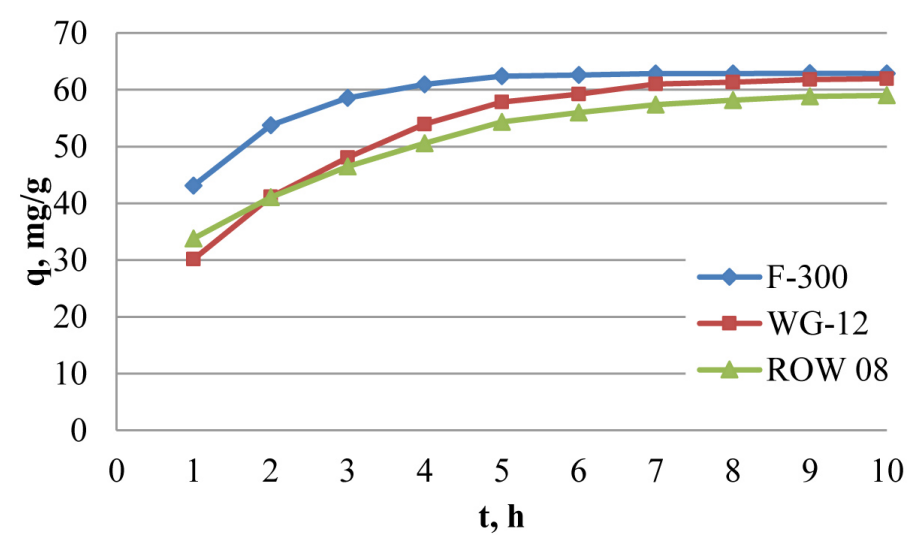

Fig. 1. Adsorption kinetics of naproxen sodium on activated carbons: F-300, ROW 08 Supra, F-300

Four kinetic models were used to describe the results: pseudo-first order, pseudo-second order, Elovich, and intraparticle diffusion (Table 1). Among the models used, the best fit for WG-12 and F-300 activated carbons was obtained for the pseudo-second order kinetics equation $\left(\mathrm{R}^{2} 0.9794\right.$ and 0.9712, respectively), and for ROW $08 \mathrm{Su}-$ pra-Elovich equation $\left(\mathrm{R}^{2} 0.9860\right)$. According to Płaziński and Rudziński (2011), the pseudo-first and pseudo-second order models are empirical and do not represent any physical model (Płaziński and Rudziński, 2011). A good match between the results obtained and the Elovich model may indicate a significant effect of chemisorption on the process effects (Tran et al., 2017). Other authors also obtained a good match between the results of naproxen sodium kinetics on activated carbon and the pseudo-second order equations (Baccar et al., 2012; Onal et al., 2007; Sarici-Ozdemir and Onal, 2010). The analysis of the $\mathrm{k}_{2}$ coefficient of the pseudo-second order kinetics equation, which characterizes the adsorption rate and the Elovich isothermal coefficient $\alpha$ (initial adsorption rate), activated carbons can be ranked as follows: F-300 $>$ ROW08 $>$ WG-12. It should be noted that the rate of adsorption is almost twice as high on F-300 than on the other two.

\section{Naproxen sodium adsorption statics}

The studies on the adsorption of naproxen sodium were conducted on three commercial activated carbons from solutions with $\mathrm{pH}$ of 6,8 and 10. In these solutions, naproxen sodium is well

Table 4. Constant equations of adsorption kinetics of naproxen sodium: pseudo first-order, pseudo second-order, Elovich and intraparticle diffusion model (Weber-Morris)

\begin{tabular}{|c|c|c|c|c|}
\hline Nonlinear forma & Parameter & $\begin{array}{l}\text { ROW } 08 \\
\text { Supra }\end{array}$ & WG-12 & $\mathrm{F}-300$ \\
\hline \multicolumn{5}{|c|}{ Pseudo-first-order } \\
\hline \multirow{2}{*}{$q_{t}=q_{e}\left(1-e^{-k_{1} t}\right)$} & $\begin{array}{l}\mathrm{k}_{1}, \mathrm{~h}^{-1} \text { - is the rate constant for the pseudo-first-order kinetic } \\
\text { model }\end{array}$ & 0.6102 & 0.5539 & 1.0629 \\
\hline & $\mathrm{R}^{2}$ - correlation coefficient & 0.8884 & 0.8374 & 0.8036 \\
\hline \multicolumn{5}{|c|}{ Pseudo- second- order } \\
\hline \multirow{2}{*}{$q_{t}=\frac{q_{e}^{2} k_{2} t}{1+k_{2} q_{e} t}$} & $\begin{array}{l}\mathrm{k}_{2}, \mathrm{~h}^{-1} \text { - is the rate constant for the pseudo-second-order } \\
\text { kinetic model }\end{array}$ & 0.0261 & 0.0218 & 0.0509 \\
\hline & $R^{2}$ - correlation coefficient & 0.8741 & 0.9794 & 0.9712 \\
\hline \multicolumn{5}{|c|}{ Elovich } \\
\hline \multirow{3}{*}{$q_{t}=\frac{1}{\beta} \ln (1+\alpha \beta \mathrm{t})$} & $\alpha, \mathrm{mg} /(\mathrm{g} \cdot \mathrm{h})$-is the initial adsorption rate & 198.68 & 115.58 & 567.10 \\
\hline & $\begin{array}{l}\beta, \mathrm{g} / \mathrm{mg} \text {-is reflected the number of sites available for } \\
\text { adsorption }\end{array}$ & 0.0843 & 0.0670 & 0.0940 \\
\hline & $R^{2}$ - correlation coefficient & 0.9860 & 0.9656 & 0.8694 \\
\hline \multicolumn{5}{|c|}{ Intraparticle diffusion model (Weber-Morris) } \\
\hline \multirow{3}{*}{$\mathrm{q}_{\mathrm{t}}=\mathrm{k}_{\mathrm{p}} \mathrm{t}^{0.5}+\mathrm{C}$} & $\begin{array}{l}\mathrm{K}_{\mathrm{p}}, \mathrm{mg} /\left(\mathrm{g} \cdot \mathrm{h}^{0.5}\right) \text { - is the slope which refer to intra-particle } \\
\text { diffusion rate constant }\end{array}$ & 11.74 & 14.35 & 7.73 \\
\hline & $\begin{array}{l}\mathrm{C}, \mathrm{mg} / \mathrm{g} \text { - is the intercept which is a constant related to the } \\
\text { thickness of the boundary layer }\end{array}$ & 25.18 & 21.39 & 41.94 \\
\hline & $R^{2}$ & 0.9405 & 0.8954 & 0.8569 \\
\hline
\end{tabular}


soluble, and at the same time, the $\mathrm{pH}$ range is in accordance with the guidelines for drinking water ( $\mathrm{pH}=6.5 \div 9.5)$ (Fig. 2). In the analysed solutions, naproxen sodium occurs in a dissociated form ( $\mathrm{pH}=6$, dissociation 98.5\%, $\mathrm{pH}=8-99.9 \%$ ). In these solutions, the compound occurs mainly in the form of anions. Regardless of the activated carbon used, an increase in the $\mathrm{pH}$ of the solution caused a decrease in the adsorption of naproxen sodium. For all activated carbons, the differences between pH 6 and 8 were small. A very clear decrease in the sorption capacity was observed when the $\mathrm{pH}$ of the solutions was increased to 10 . The observed decrease in adsorption may be related to the competitiveness of naproxen sodium anions and $\mathrm{OH}^{-}$ions, with their number greater for the higher $\mathrm{pH}$ of the solution. Both basic and acidic groups are usually present on the surface of activated carbons produced using the steamgas process. Dissociation of weak basic groups $\left(\mathrm{O}^{-}, \mathrm{COO}^{-}\right)$of the surface of activated carbons is observed in alkaline solutions, leading to the electrostatic repulsion of the sorbed anions. Similar effects of $\mathrm{pH}$ were also found by other researchers (Baccar et al., 2012; Cuerda-Correa et al., 2010). In a solution with $\mathrm{pH}=6$, dissociation of weak basic functional groups on the carbon surface and electrostatic attraction between these groups and naproxen sodium anions is likely. Taking into account the obtained adsorption capacities, regardless of the $\mathrm{pH}$ of the solution, the best results were obtained on the F-300 activated carbon, whereas the weakest were found for the ROW 08 Supra activated carbon. The F-300 activated carbon has
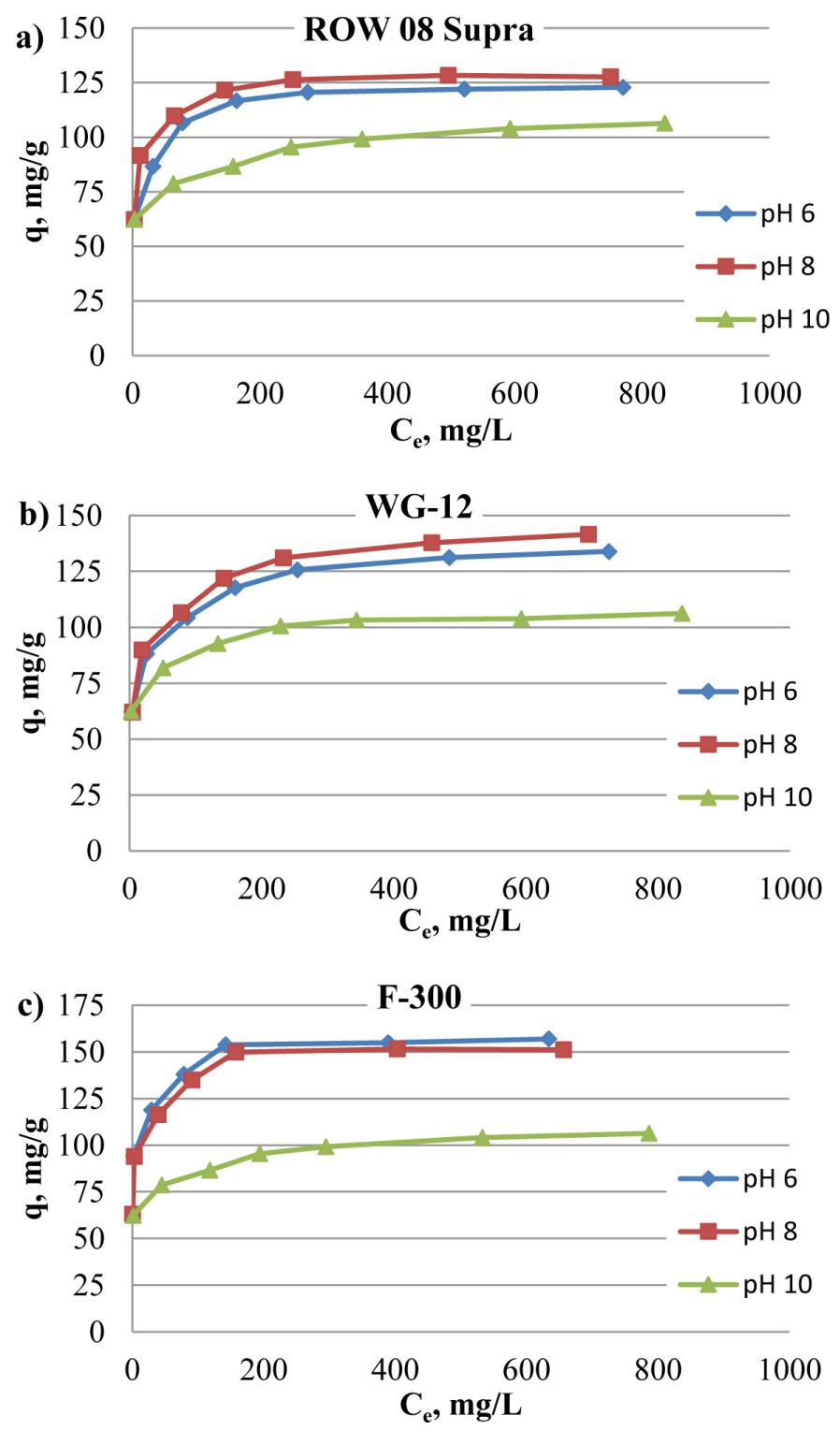

Fig. 2. Effect of $\mathrm{pH}$ on adsorption of naproxen sodium on activated carbons: a) ROW 08 Supra, b) WG-12, c) F-300 
the highest number of acidic groups and the lowest number of basic groups determined by the Bohem method (Table 3). Other activated carbons were characterized by a similar number of acidic groups. The adsorption of naproxen sodium occurred in the smallest amounts on the ROW 08 activated carbon, despite the fact that this carbon had quite a large number of basic groups. On the basis of the study results, no simple correlations were found between the number of groups on the surface of activated carbons and the effectiveness of naproxen sodium adsorption. The porous structure and availability of active places can also influence the results. However, since adsorption from the solution with $\mathrm{pH}=10$ is quite high (ca. $100 \mathrm{mg} / \mathrm{g}$ ), electrostatic interactions are not decisive during the adsorption of naproxen sodium. The F-300 activated carbon, which was the most effective in naproxen sodium absorption, is characterized by the smallest specific surface area, the smallest total pore volume and the average volume of micropores among the activated carbons tested. Therefore, physical adsorption is most likely not the decisive mechanism for the adsorption of naproxen sodium. Similarly to other nonsteroidal anti-inflammatory drugs, adsorption may result from hydrogen bonds (H-bond) between phenolic groups on the surface of activated carbon and carboxyl groups of naproxen sodium (Bhadra et al., 2016; Paul et al., 2014). The examinations of FTIR spectra confirmed the highest number of phenolic groups (the highest intensity of the bands of phenolic O-H groups that form the hydrogen bond $3200-3500 \mathrm{~cm}^{-1}$ ) on the F-300 activated carbon, which was characterized by the highest efficiency of naproxen sodium removal.

The obtained results were described using the Freundlich, Langmuir and Tempkin isothermal models (Table 5). High values of the correlation coefficient were obtained by describing the results with the Freundlich equation $\left(0.9423<\mathrm{R}^{2}<0.9835\right)$ and Temkin equation $\left(0.849<\mathrm{R}^{2}<0.9912\right)$. Adsorption on all activated carbons was beneficial because the value of Freundlich isothermal factor $1 / \mathrm{n}$ ranged from 1 and 10 (except for adsorption on WG-12 carbon from a solution with $\mathrm{pH}=10$ when $1 / n=0.0933$ ). For all activated carbons and for all analysed $\mathrm{pH}$ values, the $1 / \mathrm{n}$ values are similar and range from 0.0983 to 0.1484 . This demonstrates the diversity of active places on the surface of activated carbon. If these values are closer to 0 than 1 , as is the presented case, a low heterogeneity of the surface of activated carbons can be concluded. The advantageous nature of the process is confirmed by the value of the division coefficient $R_{L}$ ranging from 0 to 1 (from 0.001 to 0.026). The $\mathrm{K}_{\mathrm{F}}$ coefficient, which characterizes sorption capacity of activated carbons, was the highest for activated carbon $\mathrm{F}-300$ and $\mathrm{pH}=6$ $\left(\mathrm{K}_{\mathrm{F}}=83.534 \mathrm{mg} / \mathrm{g}\right)$ and the lowest for ROW 08 Supra and $\mathrm{pH}=10\left(\mathrm{~K}_{\mathrm{F}}=53.379 \mathrm{mg} / \mathrm{g}\right)$.

The Temkin equation is an isotherm that is equally well suited to the results. This isotherm, similarly to the Freundlich isotherm, assumes a monolayer adsorption and surface heterogeneity. This proves that the adsorption potential of the surfaces used in the testing of activated carbons is slightly different.

The temperature was another examined parameter that affects the effectiveness of the adsorption processes. The examinations of the adsorption of naproxen sodium on activated carbon were carried out at temperatures of 25, 37 and $50^{\circ} \mathrm{C}$ (Fig. 3, Table 5). The efficiency of naproxen sodium adsorption increased along with the temperature. The differences are quite large for all activated carbons. The process of adsorption of naproxen sodium on the carbon sorbents studied is therefore endothermic. Since physical adsorption is exothermic, this confirms the previous observations that the chemical interactions are important during the naproxen sodium adsorption. Similar tendencies were also documented by other researchers (Onal et al., 2008; Sarici-Ozdemir and Onal, 2010). An increase in adsorption following a rise in temperature may lead to the increasing mobility of molecules and an increase in affinity of adsorbate molecules to the surface of the adsorbent (Ozdemir and Onal, 2010). However, Baccar et al. found no significant effect of temperature on the process of adsorption of a pharmaceutical (Baccar et al., 2012), whereas Cuerda-Correa et al. observed a decrease in adsorption with an increase in temperature (Cuerda-Correa et al., 2010. Such a different effect of temperature was most likely caused by the differences in the structure of carbon sorbents used in the studies and different dominant mechanisms of adsorption.

The effect of the adsorbent dose on the effectiveness of naproxen sodium adsorption was also analysed (Fig. 5). The effect of the adsorbent dose was evaluated for two initial concentrations: 252 and $1008 \mathrm{mg} / \mathrm{L}$. The adsorbent doses from 1 to 10 $\mathrm{g} / \mathrm{L}$ were analysed. Similar doses were also used by other researchers during adsorption of various nonsteroidal anti-inflammatory drugs, e.g. Baccar 

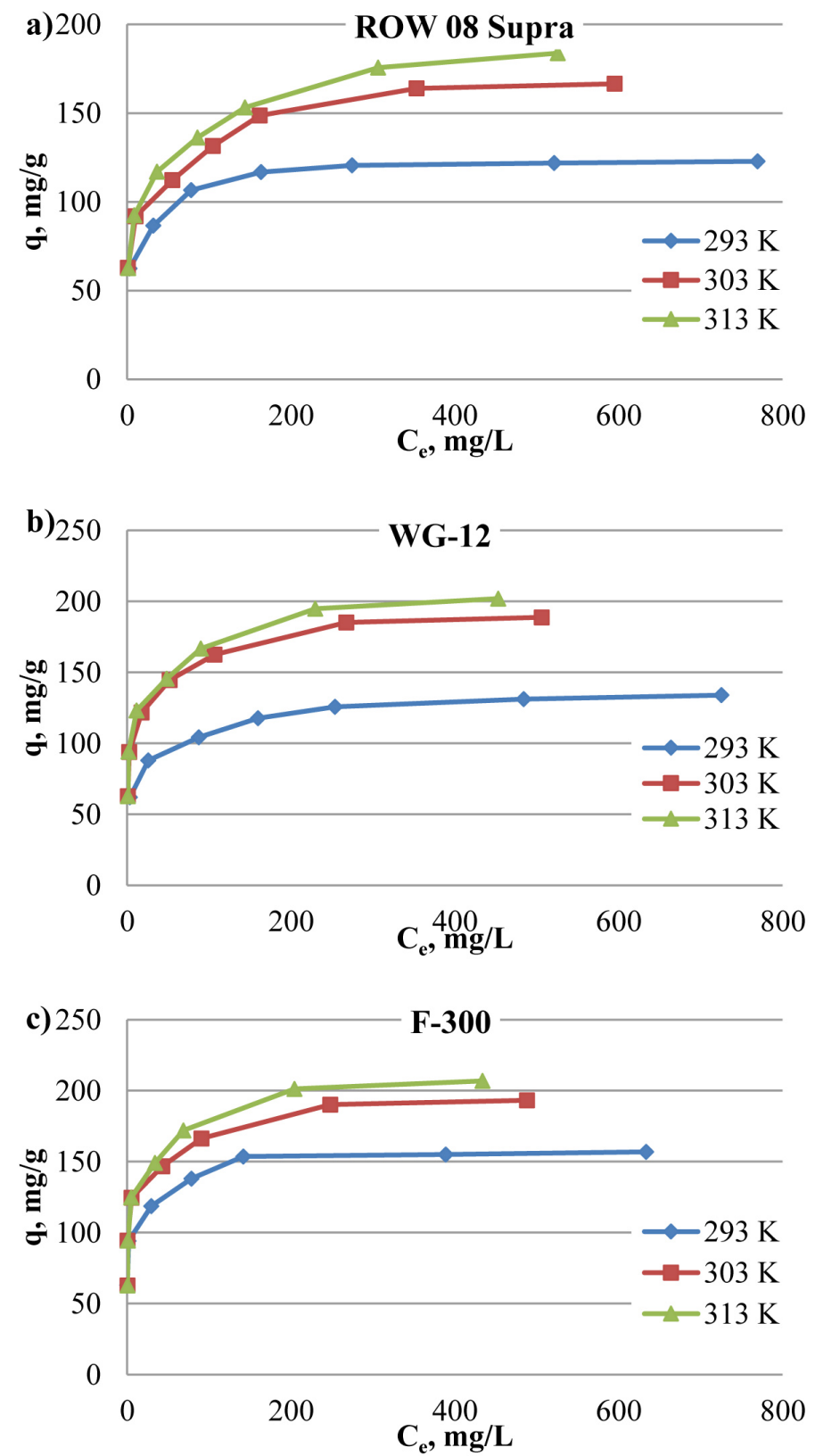

Fig. 3. Effect of temperature on adsorption of naproxen sodium on activated carbons: a) ROW 08 Supra, b) WG-12, c) F-300

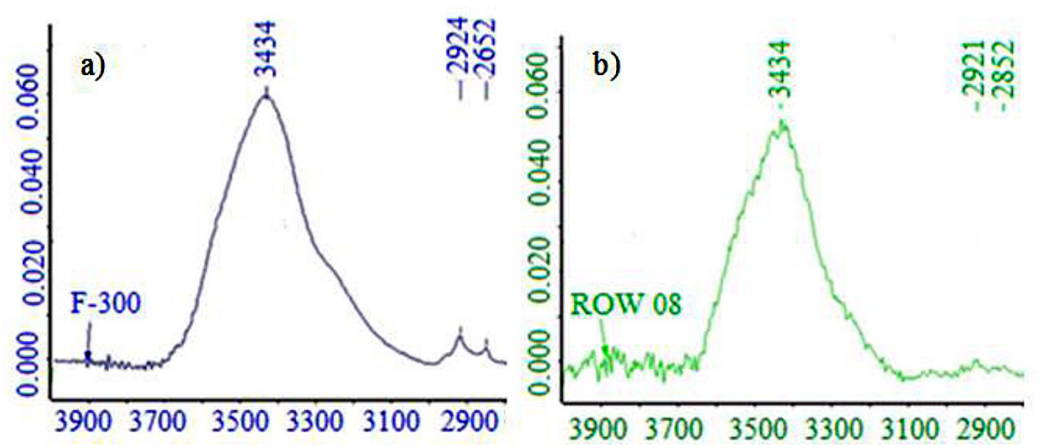

c)

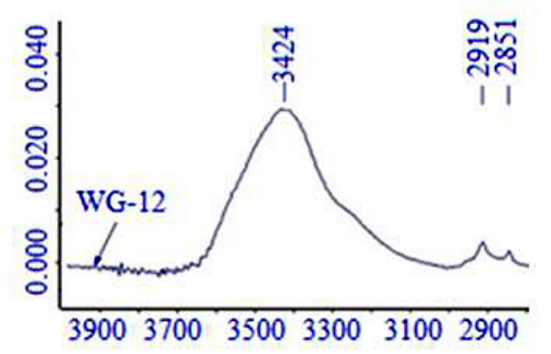

Fig. 4. FTIR spectra for activated carbons: a) F-300, b) ROW 08 Supra, c) WG-12 (part of the spectrum from 2900 to $3900 \mathrm{~nm}$ ) 
Table 5. Isothermal coefficients for naproxen sodium adsorption

\begin{tabular}{|c|c|c|c|c|c|c|}
\hline \multirow{2}{*}{$\begin{array}{l}\text { Activated } \\
\text { carbon }\end{array}$} & \multirow{2}{*}{ Parameter } & \multicolumn{3}{|c|}{$\mathrm{pH} 6$} & \multirow{2}{*}{$\begin{array}{c}\mathrm{pH} 8 \\
\mathrm{~T}=193 \mathrm{~K}\end{array}$} & \multirow[t]{2}{*}{$\mathrm{pH} 10$} \\
\hline & & $\mathrm{T}=313 \mathrm{~K}$ & $\mathrm{~T}=303 \mathrm{~K}$ & & & \\
\hline \multicolumn{7}{|c|}{ Freundlich } \\
\hline \multirow{3}{*}{ F-300 } & $1 / n$ & 0.1450 & 0.1289 & 0.1065 & 0.1103 & 0.1104 \\
\hline & $\mathrm{K}_{\mathrm{F}}$ & 89.958 & 90.877 & 83.534 & 78.831 & 58.779 \\
\hline & $\mathrm{R}^{2}$ & 0.9628 & 0.9513 & 0.9493 & 0.9423 & 0.9815 \\
\hline \multirow{3}{*}{ ROW 08 Supra } & $1 / n$ & 0.1777 & 0.1581 & 0.1159 & 0.1102 & 0.1026 \\
\hline & $\mathrm{KF}$ & 62.0178 & 62.982 & 60.373 & 65.891 & 53.379 \\
\hline & $\mathrm{R} 2$ & 0.9944 & 0.9819 & 0.9500 & 0.9423 & 0.97913 \\
\hline \multirow{3}{*}{ WG-12 } & $1 / n$ & 0.1615 & 0.1521 & 0.1393 & 0.1484 & 0.0983 \\
\hline & KF & 78.417 & 77.118 & 55.779 & 55.900 & 58.246 \\
\hline & $\mathrm{R} 2$ & 0.9657 & 0.9745 & 0.9835 & 0.9795 & 0.9733 \\
\hline \multicolumn{7}{|c|}{ Langmuir } \\
\hline \multirow{4}{*}{$\mathrm{F}-300$} & $\mathrm{q}_{\mathrm{m}}$ & 182.05 & 171.59 & 144.10 & 140.66 & 108.09 \\
\hline & $\mathrm{K}_{\mathrm{L}}$ & 0.8595 & 1.2418 & 1.6979 & 1.1067 & 0.9916 \\
\hline & $\mathrm{R}^{2}$ & 0.8519 & 0.8470 & 0.8213 & 0.8297 & 0.6607 \\
\hline & $R_{L}$ & $0.001-0.005$ & $0.001-0.003$ & 0.001-0.002 & 0.001-0.004 & $0.001-0.004$ \\
\hline \multirow{4}{*}{ ROW 08 Supra } & $\mathrm{q}_{\mathrm{m}}$ & 162.83 & 146.42 & 116.55 & 124.94 & 96.20 \\
\hline & $\mathrm{K}_{\mathrm{L}}$ & 0.1784 & 0.3160 & 0.3249 & 0.2819 & 0.5484 \\
\hline & $R^{2}$ & 0.7765 & 0.6943 & 0.8164 & 0.9522 & 0.6751 \\
\hline & $R_{L}$ & $0.004-0.022$ & $0.003-0.012$ & $0.002-0.012$ & $0.003-0.014$ & $0.001-0.007$ \\
\hline \multirow{4}{*}{ WG-12 } & $q_{m}$ & 177.460 .4550 & 168.250 .4608 & 123.90 & 132.37 & 99.28 \\
\hline & $\mathrm{K}_{\mathrm{L}}$ & 0.8376 & 0.8398 & 0.2004 & 0.1479 & 0.6460 \\
\hline & $\mathrm{R}^{2}$ & $0.002-0.009$ & $0.002-0.009$ & 0.8175 & 0.8798 & 0.7758 \\
\hline & $R_{L}$ & $0.00<-0.009$ & $0.00<-0.009$ & $0.004-0.019$ & $0.005-0.026$ & $0.001-0.006$ \\
\hline \multicolumn{7}{|c|}{ Temkin } \\
\hline \multirow{3}{*}{$F-300$} & $A$ & 66.70 & 163.29 & 677,39 & 378.21 & 378.21 \\
\hline & B & 20.43 & 17.38 & 12.53 & 12,78 & 9.49 \\
\hline & $\mathrm{R}^{2}$ & 0.9822 & 0.9680 & 0.849 & 0.9690 & 0.9774 \\
\hline \multirow{3}{*}{ ROW 08 Supra } & $A$ & 10.74 & 25.06 & 83.06 & 115.12 & 490.31 \\
\hline & B & 20.87 & 17.23 & 11.63 & 11.93 & 8.08 \\
\hline & $\mathrm{R}^{2}$ & 0.9828 & 0.9650 & 0.9563 & 0.9451 & 0.9555 \\
\hline \multirow{3}{*}{ WG-12 } & $A$ & 23.69 & 31.33 & 22.26 & 12.86 & 1034.53 \\
\hline & B & 21.86 & 19.88 & 14.11 & 15.90 & 7.87 \\
\hline & $\mathrm{R}^{2}$ & 0.9850 & 0.9949 & 0.9912 & 0.9898 & 0.9774 \\
\hline
\end{tabular}

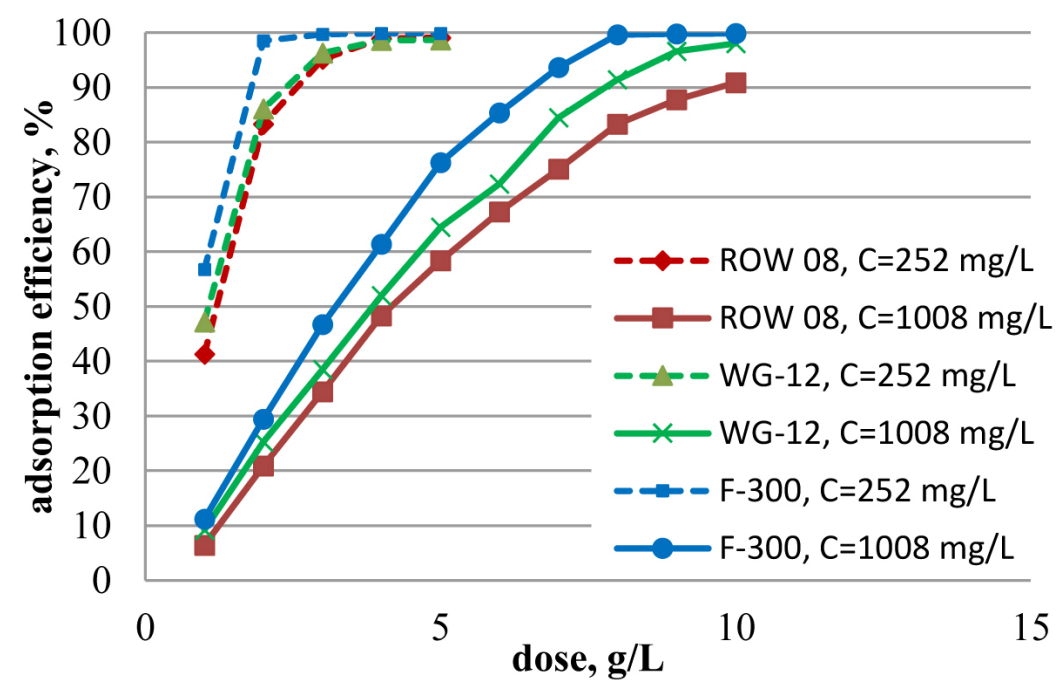

Fig. 5. The effect of adsorbent dose on adsorption efficacy at two initial concentrations of 252 and $1008 \mathrm{mg} / \mathrm{L}$ 
et al. (from 0.3 to $3.3 \mathrm{~g} / \mathrm{L}$ for naproxen sodium (Baccar et al., 2012), de Luna et al. 2017 (from 5 to $25 \mathrm{~g} / \mathrm{L}$ for diclofenac sodium (de Luna et al., 2017), Nourmoradi et. al. (from 0.5 to $10 \mathrm{~g} / \mathrm{L}$ for ibuprofen (Nourmoradi et al., 2018)). When lower concentrations of naproxen sodium were used $(252 \mathrm{mg} / \mathrm{L})$ for all activated carbons, the dose of $3 \mathrm{~g} / \mathrm{L}$ resulted in a decrease in the concentration by more than $95 \%$. In the case of a higher concentration, the dose of $8 \mathrm{~g} / \mathrm{L}$ of the F-300 activated carbon allowed for exceeding $95 \%$ of the drug removal threshold, whereas for the WG-12 activated carbon, such a dose was $9 \mathrm{~g} / \mathrm{L}$. For the ROW 08 Supra activated carbon, the removal of naproxen sodium was not exceeded $95 \%$ even for a dose of $10 \mathrm{~g} / \mathrm{L}$.

\section{CONCLUSIONS}

1. The F-300, ROW 08 Supra, WG-12 commercial activated carbons can be used to remove naproxen sodium from water because they have quite high adsorption capacities ranging from $\mathrm{q}_{\mathrm{m}}$ of $96.20 \mathrm{mg} / \mathrm{g}\left(\mathrm{ROW} 08, \mathrm{pH}=10, \mathrm{~T}=20^{\circ} \mathrm{C}\right.$ ) to $182.05 \mathrm{mg} / \mathrm{g}\left(\mathrm{F}-300, \mathrm{pH}=6, \mathrm{~T}=40^{\circ} \mathrm{C}\right)$. Adsorption of naproxen sodium occurred in the highest amount on the F-300 activated carbon, whereas the lowest amounts were found for ROW 08 Supra over the entire range of solution $\mathrm{pH}$.

2. For all $\mathrm{pH}$ values $(6,8,10)$, temperatures $(20$, $30,40^{\circ} \mathrm{C}$ ) and all activated carbons used, the process of naproxen sodium adsorption was favourable (adsorption intensity $1 / \mathrm{n}$ in the range of 1-10, distribution coefficient $R_{L}$ in the range of $0-1$ ).

3. A significant effect of $\mathrm{pH}$ on the magnitude of naproxen sodium adsorption was found for all activated carbons (the higher $\mathrm{pH}$, the lower the adsorption). This leads to the conclusion that that the electrostatic forces and chemical bonds (formation of hydrogen bonds between the carboxyl groups of naproxen sodium and the phenolic groups on the surface of activated carbons as well as the electrostatic repulsion between the anions of naproxen sodium and negatively charged surface of activated carbon) have a significant influence on the adsorption results.

4. It was found for naproxen sodium adsorption at the temperatures of 20,30 and $40^{\circ} \mathrm{C}$ that the process is endothermic (the higher the temperature, the most efficient the adsorption). This confirms the significant effect of chemical adsorption on the magnitude of adsorption of the pharmaceuticals.

5. The analysis of the results obtained for the analysed isotherms (Freundlich, Langmuir and Temkin) revealed that the highest correlation coefficients were obtained for the Freundlich and Temkin equations, whereas the lowest for Langmuir.

6. Adsorption kinetics is well-described by Elovich and pseudo-second order equations. The fastest adsorption occurred on the F-300 activated carbon (value of $\mathrm{k}_{2}$ about twice as high as for other activated carbons).

\section{Acknowledgements}

The study was supported by BS/PB-400-301/19.

\section{REFERENCES}

1. Attia T.M.S., Hu X.L., Qiang Y.D. 2013. Synthesized magnetic nanoparticles coated zeolite for the adsorption of pharmaceutical from aqueous solution using batch and column studies. Chemosphere, 93, 2076-2085.

2. Baccar R., Sarra M., Bouzid J., Feki M., Blanquez P. 2012. Removal of pharmaceutical compounds by activated carbon prepared from agricultural byproduct. Chem. Eng. J., 211-212, 310-317.

3. Baranowska I., Kowalski B. 2012. A Rapid UHPLC Method for the Simultaneous Determination of Drugs from Different Therapeutic Groups in Surface Water and Wastewater. Bull. Environ. Contam. Toxicol., 89, 8-14.

4. Bhadra B.N., Seo P.W., Jhung S.H. 2016. Adsorption of diclofenac sodium from water using oxidized activated carbon. Chem. Eng. J., 301, 27-34.

5. Boleda M.R., Galceran M.T., Ventura F. 2011. Behavior of pharmaceutical and drugs of abuse in a drinking water treatment plant (DWTP) using combined conventional and ultrafiltration and reverse osmosis (UF/RO) treatments. Environ. Pollut., 159, 1584-1591.

6. Bui T.X. Choi H. 2010. Influence of ionic strength, anions, cations, and natural organic matter on the adsorption of pharmaceuticals to silica. Chemosphere, 80, 681-686.

7. Carmona E., Pico Y., Andrau V. 2014. Occurrence of acidic pharmaceuticals and personal products in Turia River Basin: From waste to drinking water. Science of The Total Environment, 48(1), 53-63.

8. Cuerda-Correa E.M., Domínguez-Vargas J.R., 
Olivares-Marínb F.J., Beltrán de Heredia J. 2010. On the use of carbon blacks as potential low-cost adsorbents for the removal of non-steroidal antiinflammatory drugs from river water. Journal of Hazardous Materials, 177, 1046-1053

9. Czerwiński J., Kłonica A., Ozonek J. 2015. Pozostałości farmaceutyków w środowisku wodnym i metody ich usuwania. Czasopismo Inżynierii lądowej, środowiska i architektury, 62(1/15), 27-42.

10. Dada A.O., Olalekan A.P., Olatunya A.M., Dada O. 2012. Langmuir, Freundlich and Dubinin-Radushkevich isotherms studies of equilibrium sorption of $\mathrm{Zn}+$ unto phosphoric acid modified rice husk. IOSR J. Appl. Chem., 3(1), 38-45.

11. Daneshvar A., Svanfelt J., Kronberg L.2010. Winter accumulation of acidic pharmaceuticals in a Swedish river. Environ. Sci. Pollut. Res., 17, 908-916.

12. Farmakopea Polska VIII tom 2, 3. Wydawnictwa Państwowy Zakład Wydawnictw Lekarskich, 2008.

13. Feng L., Van Hullebusch E.D., Rodrigo M.A., Esposito G., Oturan M.A. 2013. Removal of residual anti-inflammatory and pharmaceuticals from aqueous systems by electrochemical advanced oxidation processes. A review. Chem. Eng. J. 228, 944-964.

14. Helenkar A., Sebok A., Zarya G., et al. 2010. The role of the acquisition methods in the analysis of the non-steroidal anti-inflammatory drugs in Danube River by gas chromatography - mass spectrometry. Talanta, 82, 600-607.

15. Hernando M.D., Mezcua M., Fernandez-Alba A.R., Barcelo D. 2006. Environmental risk assessment of pharmaceutical residues in wastewater effluents, surface waters and sediments. Talanta, 602, 334-342.

16. Kasprzyk-Hordern B., Dąbrowska A., Vieno N., Kronberg L., Nawrocki J. 2007. Occurrence of Acidic Pharmaceuticals in the Warta River in Poland. Chem. Anal., 52, 289 -303.

17. Klavarioti M., Mantzavinos D., Kassinos D. 2009. Removal of residual pharmaceuticals from aqueous systems by advanced oxidation processes. Environ Intern., 35, 402-417.

18. Lach J. 2019. Adsorption of chloramphenicol on commercial and modified activated carbons, Water, $11,1141$.

19. Lach J., Stępniak L., Ociepa-Kubicka A. 2018. Antibiotics in the environment as one of the barriers to sustainable development. Problemy Ekorozwoju, 13(1), 197-207.

20. Lindholm-Lehto P.C., Ahkola H.S.J., Knuutinen J.S., Herve S.H. 2016. Widespread occurrence and seasonal variation of pharmaceuticals in surface waters and municipal wastewater treatment plants in central Finland. Environ. Sci. Pollut. Res., 23, 7985-7997.
21. de Luna RM.D.G., Murniati, Budianta W., Riviera K. K.P., Arazo R.O. 2017. Removal of sodium diclofenac from aqueous solution by adsorbents derived from cocoa pod husks. J.Environ. Chem. Eng., $5,1465-1474$.

22. Manzo V., Honda L., Navarro O., Ascar L., Richter P. 2014. Microextraction of nonsteroidal antiinflammatory drugs from waste water samples by rotating-disk sorptive extraction. Talanta, 128, 486-492.

23. Minguez L., Pedelucq J., Farcy E., Ballandonne C., Budzinski H., Halm-Lemeille M-P. 2016. Toxicities of 48 pharmaceuticals and their freshwater and marine environmental assessment in northwestern France. Environ. Sci. Pollut. Res., 23, 4992-5001

24. Monteiro S.C., Boxall A.B. 2010. Occurrence and fate of human pharmaceuticals in the environment. Rev. Environ. Contam. Toxicol., 202, 53-154.

25. Naproxen sodium, Safety Data Sheet, sigma-aldrich.com

26. Nikolaou A, Meric S, Fatta D. 2007. Occurrence patterns of pharmaceuticals in water and wastewater environments. Anal. Bioanal. Chem., 387, 1225-1234.

27. Nourmoradi H., Moghadam K.F., Jafari A., Kamarehla B. 2018. Removal of acetaminophen and ibuprofen from aqueous by activated carbon derived from Quercus Branyii (Oak) acorn as a low-cost biosorbent. . J.Environ. Chem. Eng., 6, 6807-6815.

28. Onal Y., Akmil-Baser C., Sarici-Ozdemir C. 2007, Elucidation of the naproxen sodium adsorption onto activated carbon prepared from waste apricot: kinetic, equilibrium and thermodynamic characterization. J. Hazard. Mater., 148, 727-734.

29. Patrolecco L., Silvio Capri S., Ademollo N. 2015. Occurrence of selected pharmaceuticals in the principal sewage treatment plants in Rome (Italy) and in the receiving surface waters. Environ. Sci. Pollut. Res., 22, 5864-5876.

30. Paul S.C., Githinji L.J.M, Ankumah R.O., Willian K.R., Pritchett G.. 2014. Sorption Behavior of Ibuprofen and Naproxen in Simulated Domestic Wastewater. Water Air Soil Pollut., 225, 1821.

31. Płaziński W., Rudziński W. 2011. Adsorption Kinetics at solid/solution interfaces the meaning of the pseudo-first- and pseudo-second-order equations. Wiad. Chem., 65, 1055-1067.

32. Santos J.L., Aparicio I., Alonso E., Callejon M. 2005. Simultaneous determination of pharmaceutically active compounds in wastewater samples by solid phase extraction and high-performance liquid chromatography with diode array and fluorescence detectors. Analytica Chemica Acta, 550, 116-122.

33. Sarici-Ozdemir C., Onal Y. 2010. Study to investigate the importance of mass transfer of naproxen 
sodium onto activated carbon. Chemical Engineering and Processing, 49, 1058-1065

34. Stancova V., Żikova A., Svobodova Z., Kloas W. 2015. Effects of the non-steroidal anti-inflammatory drug (NSAID) naproxen on gene expression of antioxidant enzymes in zebrafish (Danio rerio). Environ. Toxicol. Pharmacol., 40, 343-348.

35. Szymonik A., Lach J., Malińska K. 2017. Fate and removal of pharmaceuticals and illegal drugs present in drinking water and wastewater. Ecol. Chem. Eng. S, 24(1), 65-85.

36. Tambosi J.L., de Sena R.F., Favier M., Gebhardt W., José H.J., Schröder H.F. 2010. Removal of pharmaceutical compounds in membrane bioreactors (MBR) applying submerged membranes. Desalination, 261, 148-156.

37. TogolaA., Budzinski H. 2008. Multi-residue analysis of pharmaceutical compoundsing aqueous samples. J. Chromatogr. A. 1177,150-158.

38. Tran H.N., You S-J., Nguyen T.V., Chao H-P. 2017.
Insight into the adsorption mechanism of cationic dye onto biosorbents derived from agricultural wastes. Chem. Eng. Commun., 204(9), 1020-1036.

39. Tran H.N., You S-J., Hosseini-Bandegharaei A., Chao H.-P. 2017. Mistakes and inconsistencies regarding adsorption of contaminants from aqueous solutions: A critical review. Water Res., 120, 88-116.

40. de Voogt P., Janex-Habibi M.L., Sacher F., et al. 2009. Development of a common priority list of pharmaceuticalsrelevantforthe water cycle. Water Sci. Technol., 59(1), 39-46.

41. Wang L., Ying G.G., Zhao J.L., Yang X.B., Chen F. 2010. Occurrence and risk assessment of acidic pharmaceuticals in the Yellow River, Hai River and Liao River of north China. Science of the Total Environment, 08, 3139-3147.

42. Zgoła-Grześkowiak A. 2010. Application of DLLME to isolation and concentration of nonosteroidal ant-inflammatory drugs in environmental water samples. Chromatogr., 72, 671-678. 